\title{
Paul's Letter to Philemon: a case study in individualisation, dividuation, and partibility in Imperial spatial contexts
}

\section{Paul the impresario}

Paul's letter to Philemon (composed in c. 55-56 or 56-61, depending on whether Paul is writing from an Ephesian or Roman prison) is a virtual laboratory for a discussion of themes of individualisation amongst Pauline Christ believers in the first century. As we will see, it also furnishes useful data for the discussion of dividuation, that is a study of the ancient individual as partitive, or a composite of social relations, supernatural powers, and material objects (Mosko 2010; Strathern 1988). Philemon offers a useful case study in processes of both individualisation and dividuation in a Roman imperial period emergent religious movement we today call Christianity.

In 25 short verses (335 words), Paul becomes an impresario managing an elaborate set of roles into which he casts the letter's three chief protagonists: the apostle Paul, Philemon, and a slave named Onesimus. The letter shows Paul's role as a religious entrepreneur who marshals a set of cultural codes and expectations to articulate a set of prescriptions that result in an unanticipated reversal of social norms. To the degree that this is the case, we can see that Paul is engaging in what Rüpke (2013, 3-38) identifies as de-traditionalisation, a sine qua non of processes of individualisation in ancient contexts.

As the letter unfolds, Paul, Philemon, and Onesimus (as well as a few other minor characters) find themselves occupying different positions on the apostle's stage in a rhetorical tour de force in which the imprisoned narrator masks a command in the form of an appeal to pursue a course of action that Philemon may otherwise have been reluctant to carry out. As this piece of rhetorical deliberation proceeds, the players find themselves clothed by the narrator with one costume in one or two verses, only to find themselves in new ones for a quick scene change in the next. As the rhetorical deliberation develops we discover a host of characters trying on the clothes of a shifting set of identities. The play, however, takes place on the larger stage of what our director sees as a cosmic drama. In this drama, roles must quickly change because all things are subject to a dynamic refurbishment that renders old ways of conceiving of identities and selves obsolete and requires a whole new imaginary of persons and their roles 
in a new work of divine creation. Here human actors are remade and given new scripts to follow. It is this that makes Philemon such a fascinating study in the forms of religious individualisation and dividuation that arise from an eschatologically oriented religious movement.

\section{A brief history of interpretation}

Traditionally the letter has been read as a response to a situation in which a slave, Onesimus, has run away from his master, Philemon, to seek refuge with Paul, a prisoner. The slave has been converted to Christ belief while with the apostle, who is now sending him back to his master with a letter pleading on his behalf not to punish him but to receive him as a new convert, and to free him to help with the Gospel mission of the apostle to the Gentiles (for the traditional reading, following Luther, Lohse 1973, 187, 188). In recent years, the traditional reading has been contested, with some arguing that there is no compelling evidence that Onesimus was a fugitive, only that he was sent at Philemon's bidding, was converted by Paul, and then returned to his master with a letter asking that Philemon free (or loan) his slave for the mission (Arzt-Grabner 2010, 113-42; 2004, 131-43; Lampe 1985, 135-57; Harrill 1999, 135-8; Bellen 1971, 18,78; Wolter 1993, 229-31; 2008, 169-80). Certainly, the letter remains a topic of debate amongst those who use it to argue that Paul accepted or rejected the institution of slavery (Barclay 1991). The writing has also served an important role in a kind of entangled historical reading amongst some African American biblical interpreters, who, following a liberationist strategy of a hermeneutics of retrieval, have tried to show how the Letter to Philemon forms part of a long tradition in which Paul is seen as tolerant of slavery (Barton 2016, 47-58). African American scholars point out that the epistle nowhere portrays Onesimus as a fugitive slave and that such a reading reflects more the social position of an interpretive tradition than it does the text itself. Further, they note, the apostle thus does not use the logic of his Gospel to demand Onesimus' release but instead assumes that Philemon can be both brother and master. Callahan (1997) has proffered the case that the relationship between Onesimus and Philemon was not that of slave and master but, rather, that of brothers, and that Paul's letter seeks reconciliation rather than manumission.

The more traditional historical debate has focused on whether Paul endorsed slavery. In the period before the American Civil War, Philemon functioned as an important piece of evidence for both sides of the anti-slavery/pro-slavery debate (Callahan 2012, 143-56). Pro-slavers argued that the letter, taken together with 
the Household Rules (Col. 3.18-4.1; Eph. 5.22-6.9; 1 Pet. 3.18-3.7; 1 Tim. 2.8-15; 3.2-13; Tit. 1.5-9 - a hierarchically arranged list of duties assigned to husbands, wives, children, master, slaves), in which Paul (both parties assumed Paul wrote everything the New Testament ascribes to him, a position many scholars contest) exhorts slaves to be obedient to their masters, shows that the apostle tacitly endorsed, if not directly promoted, slavery. Abolitionists pointed out that Paul urged Philemon to release his slave and encouraged slaves to seek their freedom where possible (1 Cor. 7.22), thus showing his opposition to slavery. In fact, this debate could itself form the backdrop for an interesting case study in questions of the individualisation of slaves in the slavery debates of the 18th and 19th centuries, and of how the Epistle to Philemon played a crucial role in de-traditionalising slavery to affirm the rights and individuality of every person. Here, however, we focus on the place of the letter to Philemon as a letter in its first century context, since it furnishes us with a fascinating case study of first-century individualisation and notions of divine presence in constituting religious identity more broadly.

\section{The anthropological turn}

There is a school of New Testament scholarship that would contest the very possibility of evidence of individualisation in a document of the first century. Starting in the 1980s, a group of biblical interpreters, who went on to form a seminar called The Context Group, turned to the tools of cultural anthropology to study the Bible. ${ }^{1}$ Arguing that biblical scholars too often import modernist assumptions into ancient data and thereby misinterpret ancient evidence with a contemporary mindset, they turned to cross-cultural comparison with modern Mediterranean and contemporary peasant cultures in order to create models appropriate for the interpretation of the Bible, whose texts, they argued, were far closer to traditional peasant ways of seeing the world than they were to those of the Enlightenment and the industrial west (for a general introduction, Esler 2000, 3-25). The members of the Context Group were, and continue to be, extraordinarily prolific authors who together have published dozens of monographs, commentaries and scholarly articles, convened international seminars, and supervised scores of doctoral theses. The result has been a transformation of the field of biblical studies, especially in North America and Great Britain. Today, if one picks up a

1 For the Context Group, 'The Context Group: A Project on the Bible in its Socio-Cultural Context', http://www.contextgroup.org (cited 31.12.2016), of which the author is a member. 
New Testament introduction in the English-speaking world one sees evidence of leading concepts of the Context Group invoked without citation as received scholarly wisdom.

In 1981, Bruce Malina, one of the pioneers of this approach, published The New Testament World: Insights from Cultural Anthropology. In it he distilled an array of anthropological field studies, largely by scholars publishing in the 1960s, in order to identify what he described as 'pivotal Mediterranean values'. These, he argued, were the coordinates that should guide any exegetical study of biblical texts that seeks to avoid cultural anachronism and remain faithful to the probable meanings of ancient texts. The values include honour and shame, the dyadic personality, the idea of limited good, kinship structures, and concerns over purity and impurity. In Malina's treatment, these are what define a Mediterranean peasant society and what we can generalise as the primary characteristics of the contemporary cultures of the Mediterranean Basin, which in turn furnish us with the means to engage in culturally appropriate investigations of the first century. Behind his approach is Braudel's representation of the longue durée, presented in The Mediterranean and the Mediterranean World in the Age of Philip II (1949), although Malina pays little attention to the shifting dynamics of Mediterraneanism (the many Mediterraneans, the French historian insisted) of the Braudelian enterprise. It is notable that although anthropologists have for decades now contested an idea of 'the' Mediterranean (Herzfeld 1984; 1987; de Pina-Cabral 1989), Mediterraneanism and the abstract totalising generalisations that marked an earlier generation of anthropologists now passes wie es eigentlich gewesen within the New Testament guild and reproduces itself through its many media.

For our purposes here, we will attend to Malina's pivotal value of the 'dyadic personality'. For Malina and others, this phrase refers to a notion of the individual and the self that characterises pre-industrial, peasant culture. Applied to the ancient Mediterranean context, the central insight of the concept is that, unlike in the case of modern people for whom individualism and introspection form central aspects of their social identity, the ancients had neither an interest in, nor indeed a capacity for, introspection, and had no notion of the individual. Instead, ancient people conceived of themselves as occupying social roles and carrying out the obligations associated with them. They were relationalists, not individualists. While the modern self is a bounded unit, the ancient self was social and inter-related. Thus performance dictated by the traditions associated with time-sanctioned societal scripts is what created social identity. As people were governed by codes of honour and shame, this meant that there was little deviation from these prescribed relational roles without the severe consequences of social marginalisation. 
On this account, we can only speak of individuals in the ancient world as people governed by psychosocial roles - more or less flat characters practicing their daily lives in the company of others without reference to an interior life. The exclusive reference point for the ancients was to the others outside oneself and it was by reference to these that one knew oneself and undertook daily practices. Mediterranean dyadism contrasts with modern individualism through its determinative group orientation.

A dyadic personality is one who simply needs another continually in order to know who he or she really is [...]. Such a person internalizes and makes his own what others say, do, and think about him because he believes it is necessary, for being human, to live out the expectations of others. That person would conceive of himself as always interrelated to other persons while occupying a distinct social position both horizontally (with others sharing the same status, moving from center to periphery) and vertically (with others above and below in social rank). Such persons need to test this interrelatedness, with the focus of attention way from ego, on the demands and expectations of others who can grant or withhold reputation. Pivotal values for such persons would be honor and shame, not guilt.

(Malina 1981, 55)

Malina's mention of guilt here refers to a modern theological sensibility that reads ancient biblical texts, especially those from Paul, as a solution to the human dilemma of how a guilty sinner can stand before a righteous God. On this model, Martin Luther and, before him, Augustine, possessed the quintessential introspective religious consciences of the west (Stendahl 1963). As ancients had no interest in, or perhaps even capacity to experience, guilt and had their entire psychosocial make-up dedicated to what others thought of them, any attempt to discover first-century people as individuating selves must be anachronistic at best. Malina goes on to state,

The dyadic personality is an individual who perceives himself and forms his self-image in terms of what others perceive and feed back to him. He feels a need of others for his very psychological existence, since the image he has of himself must agree with the image formulated and presented by significant others, by members of significant and personsustaining group like family, village, even city and nation.

(Malina 1981, 55)

We can freely acknowledge the obvious point that ancient people were not like us moderns and that we cannot step into the past with our understandings of personhood. However, when stated in as bald a form as that offered by Malina, it is a gross distortion of the evidence to replace guilt-ridden modern individualists perpetually given to existential crises with a set of ancient cyphers who had no real capacity to conceive of themselves except through menus of social roles and the perceptions of others. The strength of Malina's approach is to draw attention to the role of social expectation and codes of honour as important 'sources of 
self' (Taylor 1994) in Antiquity. Michael Trapp (2007), in his survey of personhood and its relation to ethics and social identity in the Hellenistic and Roman period, confirms some of what Malina contends, albeit without reference to social scientific models in the service of a Braudelian Mediterraneanism. Trapp points to the importance of conformity in the making of ancient selves and to the kind of quirky individualism modern people celebrate as a problem to be overcome rather than an identity to be nurtured and promoted in others. What Malina fails to perceive, however, is that actors always have choices about how they will conduct the practices that belong to the duties and obligations they are tasked with living. Nor does he appreciate that psychosocial interactions are, while relational, far more complex than the 'dyadic' model permits. It is true that ancients were members of collectives such as families, cities, and social strata, and that they negotiated their lives by reference to social scripts. But it does not follow that they did not do such things in idiosyncratic ways. The problem is that while Malina's dyadic person resolves the problem of not reading ancients as moderns, it creates another, even more serious, problem by turning ancients into little more than individualised versions of group stereotypes. Further, while we cannot speak of ancient selves as modern individuals, neither should we turn them into simple functions of social expectations and exchange.

Charles Taylor's (2007, 35-41) notion of the porous self of the pre-modern period is useful here. The phrase describes a non-bounded self that is subject to and constituted by innumerable phenomena (spiritual powers, powers of objects, religious rituals, magic, relationships with physical surroundings and natural phenomena, shifting identities in varying situations, gift exchange, and so on) as well as interpenetrating others through different kinds of media (spells, prayers, sacrifices, gifts, invisible transference of parts of oneself into another, etc.). The porous self is one capable of interpenetration and relationships that moves far beyond the enacting of traditional roles. Instead of speaking of selves as dyadic, as Malina does, we should therefore consider them 'polyadic', polypositional, and multifaceted. They were not at all like modern selves and individuals, but they were selves and individuals nonetheless.

This is where attention to Paul's letter to Philemon is helpful, because it invites us into a world that is neither modern nor flatly 'Mediterranean' but, rather, points to forms of agency that unfold within a set of culturally expected roles. The value of Paul's letter to Philemon is not that it assures us that honour and shame are guiding categories in the life of ancients (which they surely were), nor that we can see people governing themselves by reference to the perception of others (which they most assuredly did). Such notions can readily be detected in Paul's letter to Philemon and thus could be invoked to sustain Malina's overall model. It is rather that we see creativity in how a set of religious beliefs create new 
possibilities for social performance and for casting those performances within a new set of narratives. We see the agency of a religious entrepreneur negotiating social codes and expectations in new ways to bring about ends that conform to a novel set of religious beliefs and practices.

\section{Dividuation and partibility}

A more promising and valid avenue for cross-cultural anthropological discussion of individualisation in the Letter to Philemon can be found in a recent study of dividuation and relationality in Melanesian culture. Here the self is not comprised by a static set of psychosocial roles but rather by interpenetrating relationships with people, places, and objects. Strathern (1988), in her study of gender in Melanesian culture, deploys the term dividuation in reference to persons 'frequently constructed as the plural and composite site of relationships that produce them' (13). The dividual is both single agent and cause of effects, but it is also multiple. 'The singular must also be seen with respect to the two forms out of which unity is composed - the multiple or composite person and the dividual. Here what is taken for granted are the multiple external relations in which a person is embedded [...]' (275). This means that when a person acts as an in/dividual s/he is also acting as a plurality: 'a person in the form of a dividual, is potentially one of a pair [in taken-for-granted relationships], or may know him or herself as a composite microcosm, potentially bounded as a unit' (275). On this model, a person acts as a subject but does so self-reflexively, that is, in view of the observation of others (whether real or imagined), such that an in/dividual act also becomes a united act of a group that the actor performs and is judged thereby to be successful or not. Strathern furnishes the example of a woman giving birth, which is an action by an agent but also a microcosm of social relations:

what gives the event its unique character is how well or in what manner a particular relationship is made "to appear" on that occasion. That evaluation defines the occasion. The event thus submits the self, the agent, to scrutiny in its capacity as a person from the vantage of another and thus subjects it to aesthetic judgment (278).

The notion of a Mediterranean dyadic relationship is thus too simple and restricted. On the model of dividuality, the role of the other is not simply to script a stereotypical set of performances and behaviours according to which one knows oneself and the other. On the contrary, there is a rather more dynamic relationship: 'The character of the other provides the context that determines whether the agent perceives her or himself as effective in a dividual and multiple mode' (278). 
A further feature of dividuality, where there is both individual agency and a microcosm of social relations, is partibility, that is the constitution of a person through gifts, contributions, and the splitting off of or detachments of others. Mosko (2010, 215-40) has studied the manner in which conversion to Christianity is effected in particular Melanesian cultures 'through elicitive exchanges involving parts of their persons and corresponding personal detachments of God, Jesus, Mary, Holy Spirit, the Devil and so on' (215). He describes how, in conversion or other forms of religious transformation, a person's composition changes through attachments to the contributions of others or through detachments from one agent to another.

Through acting, partible persons are decomposed, anticipating and evincing recognition of their externalized capacities through the responses of corresponding patients (or victims [i.e. in magical spells]). For me to detach the appropriate part of myself so that it will be effective in drawing forth a desired part of another person (i.e. his or her sister in marriage, a shell valuable, or a ritual spell) I must be able to conceptualize the internal capacities of both myself and my exchange partner so that I can strategically externalize that part of me which will be successful in uncoupling the part of the other person which I desire. Through these kinds of elicitations, persons stimulate one another to action and reaction. Every action - or transaction - is in this way both conventional and innovative.

(Mosko 2010, 218)

Thus dividuality and partibility offer a way to conceptualise a non-western form of in/dividualisation wherein selves are not buffered but porous, and are found in roles and practices even as they are constructed from a variety of causal agents, including those of gift exchange. This last point is especially important for an understanding of the kind of individualisation under investigation in this treatment of Philemon.

\section{Narrative worlds and personae in Philemon}

Such cross-cultural social scientific studies prove especially useful in the interpretation of ancient biblical texts. Distant comparisons between New Testament writings and other pre-industrial cultural systems free one from modern assumptions and allow one to enter imaginatively into other cultural social worlds. While one cannot simplistically impose the anthropological study of Melanesia onto ancient Mediterranean Christ religion, there is nevertheless sufficient 'fit' to allow comparison and thereby to bring aspects of biblical texts and the religion they represent into relief. In what follows I present first an account of the narrative world of the letter to Philemon and then draw on notions of a dividual and partible self to explore aspects of the correspondence that have not yet been explored. 
Norman Petersen's notion of 'the sociology of narrative worlds' (Petersen 1985, 17-29) provides a valuable approach to the evidence for, and forms of, individualisation, dividuality, and partibility in Paul's letter to Philemon. With the help of the sociology of knowledge, he invites a study of Paul that considers the apostle and his letters as belonging to intersecting narrative worlds: the narrative we create as historians looking onto the past, Paul's narration of the world around him, and the implied narrative that lies within, embedded and behind each letter in his corpus. This implies a dynamic set of relations at multiple levels of investigation. What he means by a 'sociology of narrative worlds' is a study of 'the symbolic forms and social arrangements that sustain the lives of the actors who inhabit such [narrative] worlds' (17). Petersen goes on to consider two features of such forms and arrangements, namely the structures of social arrangements within a group and the meanings maintained by the group. My own predilection is to speak of roles and drama, rather than 'groups', because there is a tendency by Petersen - under the influence of the sociology of knowledge - to reify social performance and render it too static. This follows as well from his use of Geertz's (1973, 87-125) notion of symbol systems as models of and models for reality. Without diminishing Geertz's anthropological insights concerning the importance of attention to how symbols create and prescribe actions within reality, it is more fruitful when considering the issues of in/dividualisation in Philemon, and arguably the corpus Paulinum more generally, to consider lived practices, competing commitments, and creative appropriations of symbol systems. Cultures are dynamic lived realities that are remade in each encounter in sometimes-unpredictable ways (de Certeau 1984). To put it differently, while a set of symbol systems may serve to define reality and ethical codes, not all people will interpret reality identically or act uniformly. A host of factors, such as gender, social status, and psychological factors, result in idiosyncratic ways of seeing and acting within the world. This calls for a more dynamic model for the interpretation of narrative worlds and the roles that unfold within them.

To follow Rüpke (again), Philemon points toward practices de-traditionalisation, namely the reconfiguration of behavioural norms, cultural patterns, and religious beliefs for new purposes.. The net result is new modes of performativity that result in individualisation, here understood as the emergence of new modes of action and practice guided by a particular religious narrative and its differing, and by no means always internally self-consistent, interpretations amongst various social actors. To put it differently, even those who inhabit the same religious narrativisation of the world will not occupy it in the same way, or even tell the same story at all times to themselves or to one another. The Letter to Philemon is one moment created by one storyteller and directed towards others who will receive and retell the story in their own ways. However, when considered 
from the perspective of dividuality and partibility, the letter also creates selves and others, both via detachment (the letter as expression and token of self) and attachment (the letter's arrival and its effects - considered to elicit a transformation of self-identity - in reading).

Paul pitches this re-traditionalisation in the particular modality of one patron/religious entrepreneur communicating with another with respect to a third party. At one level the social codes are maintained, but this serves as a backdrop for their deconstruction at another level. It is within a shifting narrative configuration of identities that social roles are de-traditionalised, thus creating actors for new roles and self-understandings. Here there are others who help to shape the perceptions of a self and by reference to whom one sees and interprets oneself. To consider this self-other interrelation in a kaleidoscopic narrative fashion avoids the error of Malina, who would make Paul's letters all stage setting, props, and cultural generalities, but leave no room for real actors. It also avoids the limitations of the approach taken by Petersen, who would make of Paul and his audiences all group and no individuals. My interest is in the way Paul furnishes us with people to place on Malina's stage and within Petersen's group, and on the unique roles he gives them to play in a surprising narrative twist that serves to individualise them, as well as on the way the letter conceives interpenetrable and partible in/dividuals. We will see directly that the Letter to Philemon reflects the acting out of a small scene in a larger apocalyptic drama, into which Paul inserts his characters, thereby seeking to transform the broader setting. Here there is a capacity for the actors to detach parts of themselves and to attach to others, resulting in new constructions of what constitutes an individual and relationships amongst actors. To demonstrate this, we will need to look beyond the confines of our 335 verses to the larger Pauline corpus and the sources of self the apostle identifies there.

First, however, it is necessary to take a closer look at the players in the particular scene represented by the Philemon letter. In order to get the full measure of Pauline de-traditionalisation and in/dividualisation in the epistle, it is helpful to chart the set of roles Paul invokes and how he (usually implicitly) reverses them by bringing them into association with one another. What I mean by roles is a set of more or less stable cultural codes and prescribed practices that an ancient might expect someone inhabiting the role to perform in the accomplishment of their duties. I begin by offering a table of the roles the letter invokes. I want to conceive this more as a list of dramatis personae than 'roles' because, following de Certeau's theorisation of daily practice as well as Strathern's observation concerning agency that is simultaneously constituted by the individual and the group, I want to show that we are dealing with practices and dynamic relations that have the power to affect one another rather 
than with static identities. The following lists these practices and relationships, following the NRSV translation of the Greek, together with the verses in which they appear.

1. Paul
a. prisoner of Christ Jesus $(1,9,23)$
b. prisoner for the Gospel $(1,9)$
c. brother of Philemon $(7,20)$
d. old man/ambassador (9)
e. father of Onesimus (10)
f. Onesimus as 'my own heart' (14)
g. master (13)
h. partner with Philemon (17)
i. patron of Onesimus (18)
j. author (19)
k. 'in Christ' (20)
1. client of Philemon $(20,22)$
m. master of Philemon (21)

2. Philemon
a. dear friend (1)
b. co-worker (1)
c. house church host (2)
d. love for the saints and faith (5)
e. evangelist (6)
f. patron $(2,7,19,20,21)$
g. brother of Paul $(7,20)$
h. brother of Onesimus (16)
i. $\quad$ servant/slave $(8,21)$
j. $\quad$ slave owner $(11,16)$
k. partner (17)
1. Paul's client (19)
m. 'prayer' (22)

3. Onesimus
a. Paul's child (10)
b. once useless now useful (11)
c. servant/slave $(12,16)$
d. Paul's heart/proxy for Paul $(12,17)$
e. proxy for Philemon (13)
f. brother (16)
g. 'in the Lord' (16) 
4. Others
a. Timothy - brother (1)
b. Apphia - sister (1)
c. Archippus - fellow-soldier (1)
d. Epaphrus - fellow-prisoner in Christ (23)
e. Mark, Aristarchus, Demas, Luke - fellow workers (24)

The table, as abstract as it is, offers occasion for a few preliminary observations. First, it reveals the plurality of roles Paul ascribes to the characters of his letter and the speed with which he exchanges them. Second, these roles can be broken down into a set of categories that relate to solidarity (the frequent use of 'co' or 'fellow' and 'partner'); friendship, patronage (host, owing of self), clientship (guest), the household (father, sister, child, master, slave), the body ('heart'), religious belonging/location ('in Christ'), government (ambassador), imprisonment, and the army. Third, we can see here that Paul is playing at a register of keys and following a score not directly visible in the letter itself but presumed throughout it. Finally, and most importantly, this is what makes the letter such a fascinating case study in what might count as individualisation, as well as dividuality and partibility. The letter provokes Philemon to realise Paul's desired outcome, which is to receive Onesimus as Paul's own self and then to free (or loan) him for the apostle's (that is to say, God's) task of proclaiming his Gospel.

One witnesses a straightforward script that combines notions of friendship together with those of patronage, but also a social account of one giving a piece or part of oneself to another that results in a change in the other. Thus, on one level, Paul addresses Philemon as a social equal when he refers to him as co-worker, dear friend, and partner. He is cognisant of the fact that since Philemon welcomes an assembly of believers in his household, Philemon is also a patron. Indeed, the apostle is bound to him on the basis of a cultural script of exchange of favours: Paul will reimburse Philemon for anything the return of Onesimus may cost the master and he relies on his hospitality, even as Philemon owes to Paul his own self as a convert to Christ belief.

From the perspective of dividuality and partibility, the gift exchange of hospitality, patronage, friendship, and favours binds both actors together and, in doing so, also changes them. When Paul describes himself as Onesimus' father and Philemon's brother he is describing a changed set of relations that go far beyond the metaphorical status of religious roles and practices. This language describes transformations of relationships both through the imparting of spiritual gifts from God and through attachment to spiritual gifts that are tokens of the presence of a partible deity that inhabits believers, as well as of partible selves. In sending Onesimus, Paul sends Philemon 'his heart' - that 
is to say a part of himself that now enters into Philemon's social world and changes him through a ritual of eastern Mediterranean gift exchange. Such gift exchanges establish both equalising and hierarchical relations between these actors. In offering Onesimus welcome, Philemon welcomes Paul as a friend as welcoming a part of Paul's own self; in sending him, Paul expresses his fatherly presence and reminds Philemon that he too is the host's father, indeed Philemon owes Paul his very life ('you owe me your very self' - v. 19). Do these obligations cancel each other out? Or are they arranged hierarchically so that any bonds of gift exchange that might exist nevertheless appear in a hierarchy of benefits and returns? Without saying it, Paul clearly wants to affirm such a hierarchy. Thus it is that he can command by requesting that Philemon does what Paul wishes. Paul (as a proxy for Christ) retains the privilege of a primary locus of agency, even as such privilege is disavowed by his repeated self-representation as a prisoner.

Yet if there is a hierarchy of gift exchange, it is an inverted one that can be seen in Paul's inversion of normal indices of status. There are two stage sets in this letter: the one is Philemon's house church and the other is Paul's prison. Between these settings, selves are imparted and reconstituted in a unique new microcosm of a recreated social world. The presence of the house church looms large as the epistle's backdrop. The epistle is a personal letter to Philemon but, as v. 3 indicates, the recipient is also host to the Christ assembly that meets in his house. The other setting, the prison, is more important for the apostle's rhetorical purposes: Paul represents himself as a prisoner four times (vs. 1, 9, 10, 13), thus making his imprisonment a critical motif in his epistolary character. The social shame of imprisonment is, however, inverted when Paul describes himself as a 'prisoner of Jesus Christ' (vs. 1, 9) and his jail time as 'imprisonment for the gospel' (v. 13). The fourth reference (v. 10) makes the prison the locale of Paul's exercise of patriarchal authority in becoming father to Onesimus, 'my child' (v. 10). It is clear that this is no normal Roman jail: Paul is not Rome's prisoner but Christ's, and his cell is a setting for adoption into a new family of believers. This makes for a topsy-turvy identity, as can be seen in the inversions of v. 8: '[T] hough I am bold enough in Christ to command you to do your duty, yet I would rather appeal to you on the basis of love - and I Paul, do this as an ambassador [presbytēs], and now also a prisoner of Christ Jesus [desmios Christou Iēsou]' (my translation). This imprisonment has changed Paul in the same way that detachment from a divine power that now inhabits him changes him: he is not a prisoner of Rome, but of Jesus Christ $(1,9)$. Location imparts to him a new status which creates a modality of self that allows the imprisoned apostle to issue commands from a superior social location. Here he is in prison but, more critically, he is also 'in Christ' (v. 20). With the apostle is 'his heart' which he has sent in the guise of 
Onesimus to Philemon to refresh is an extension of this identity: 'I am sending him back to you, sending my very heart' (v. 12); 'refresh my heart in Christ' (v. 20).

Modern Western notions of the buffered self quickly lead one astray when encountering this language. This is a world in which agency is distributed through gift exchange that makes selves partible and dividual, as well as interpenetrable. The setting here is, thus, not neutral but, rather, a locus of agency; it inhabits Paul even as he is within it. Here, in his oxymoronic representation of himself as ambassador/prisoner, Paul undertakes a wholesale revision of cultural expectations. This allows him to reconceive whatever duty Philemon the slave master has towards his property Onesimus as a new set of priorities that reflect Paul's own reversal of identity, inscribed by the overlay of his narrative world onto his physical setting of imprisonment. This helps to turn Onesimus into a brother of his erstwhile master, even as both are brothers with Paul. The apostle creates a new set of fictive kinship relations in that all the players in our drama are children of their heavenly father, God. Indeed, how they will be a father and brothers is the product of their own idiosyncratic behaviours. But whether they will be such is ultimately determined by their audience, namely God, who witnesses the outcomes and behaviours of these exchanges. We are not, of course, in the village of a woman giving birth in Melanesia. However, the transactional observational culture of that setting offers an interesting means for making a cross-cultural comparison that we might otherwise miss when confined to study that is strictly lexicographical and oriented towards the sociology of knowledge, or indeed towards outmoded 1960s anthropological analysis.

Agency and identity here are much more sophisticated than traditional avenues of interpretation usually permit. In the case of our characters, it remains only for Philemon to get up to speed on Onesimus' new status as a believer and to receive him no longer as slave but also as brother, 'both in the flesh and in the Lord' (v. 16). They share an interpenetrating transactional set of relations made possible through divine habitation. Under such a new set of relations, it is hardly appropriate for Paul to invoke his right to command Philemon (as though an apostolic master over the person who owes him his life). Rather, he should appeal to Philemon to act voluntarily (v. 14). Here Paul borders on the language of master and slave himself. He does not want to compel or force Philemon to do anything (v. 14) and he wants Onesimus to act as proxy for Philemon: 'that he (Onesimus) might be of service to me in your place during my imprisonment for the Gospel' (v. 13) - again marking the capacity of selves to fuse with others in new constellations of dividuality.

The way that the letter flips relations between patrons and clients, slaves and masters, freedom and imprisonment, shows a complex revision of social identities and protocols even as it communicates a set of dynamic dividual identities. 
Paul as religious entrepreneur improvises on social hierarchies and practices of exchange, as well as indices of honour and status, in a way that both inscribes and undermines traditional understandings and relocates actors within a constellation of new interpenetrating realities. The result is a dynamic social script that cannot be apprehended by reference to a simplistic notion of dyadism but requires instead attention to the subtle reworking of cultural scripts in the particular social situation created by a slave, a master, an assembly of religious adherents, and a religious founder. It is practice and both individual agency and collective identity that together create a process of in/dividualisation, not a timeless and static cultural phenomenon. Porous selves practice a set of social interactions and are in turn changed by them.

\section{Cosmic in/dividuation}

The letter attests to the importance of a religious imaginary in processes of individualisation (Fuchs 2015, 333-5). The letter to Philemon, as indicated above, is but a scene in a much larger drama that Paul conceives of for himself and those around him. It is on the basis of a larger imagined drama that the forms of detraditionalisation of social roles, created by Paul's appeal to Onesimus' master, take shape and create new possibilities for social performances and identities. It is to this larger social and religious imaginary that this essay now turns.

There is debate as to whether Paul is an eschatological (Wright 2013; 2015) or apocalyptic thinker (Beker 1982). While appeal to an Inter-testamental form of Jewish apocalyptic has been used with too heavy a hand to interpret Paul's uncontested letters (thus, Sanders 1977), it is important to recognise that, for the apostle, there is a radical refashioning underway that will be realized through a reformulation of human relations in an impending advent of Christ. 'For the Lord himself will descend from heaven with a cry of command, with the archangel's call, and with the sound of the trumpet of God' (1 Thess. 4.16). Paul conceives of an old age passing away and a new one arriving (2 Cor. 5.17), even as he anticipates the second coming of Jesus with all the fanfare one discovers elsewhere in Second Temple apocalyptic literature. Because of the in-breaking of this new order, social horizons are being reformed.

'[T]he appointed time has grown very short; from now on, let those who have wives live as though they had none, and those who mourn as though they were not mourning, and those who rejoice as though they were not rejoicing, and those who buy as though they had no goods, and those who deal with the world as though they had no dealings with it. For the form of this world is passing away' (1 Cor. 7.29-31). 
Perhaps one might gloss this text with an additional phrase: and masters treat slaves as brothers and sisters, and those imprisoned in Christ Jesus as ambassadors of the Gospel. For Paul, all traditional arrangements are in a process of being recast: 'For as many of you were baptised into Christ have put on Christ. There is neither Jew nor Greek, there is neither slave nor free, there is no longer male and female; for you are all one in Christ Jesus' (Gal. 3.27-28). Slaves and masters are brothers and sisters, those imprisoned are most honoured, traditional gender arrangements are recast, and imperial powers are being swept away in favour of a new means of governance and human sociality.

It falls outside the strict confines of this essay to chart all the nuances of this recasting of social relations. Suffice it to say that, in the light of this renewal that is 'even now but not yet', Paul represents a profound de-traditionalisation of social roles and hierarchies in favour of a new set of possibilities for exercising social agency and identity. Paul does not see a gradual coming of a new order but a radical break in the present social order and a sweeping away of old realities in favour of a new ones. An old creation in bondage to sin and death is being renewed and is indeed groaning with birth pangs as the new one is arriving (Rom. 8.22-23). This allows Paul to prescribe new sets of social relations in the midst of a passing order: male-female relationships are not defined primarily by marriage and the household (assuming that Paul did not write Colossians or Ephesians), men and woman should not marry if they can help it, there is no longer slave and free, Jew or Greek, male and female. A new thing has come and old things are passing away. This creates the stage for the de-traditionalisation of social roles and behaviours and the emergence of new personae living out roles in unique and unanticipated ways. In terms of the composition of selves and identities, for Paul this reality that is passing away is marked by the penetration of the self by the Spirit. Paul conceives of identities that can be possessed by a partible and dividual God, as well as identities that can at one and the same time be 'in the Spirit' and 'in Christ', and even joined to the death of Jesus in crucifixion.

We are all too familiar with this language and, from a modernist theological point of view, tend to overlook the way in which it marks dynamic identities being constructed by powers that are detached from God and which inhabit Christ believers. Paul uses the language of 'the gifts' or 'fruits of the Spirit', which moderns are inclined to understand with a rationalist mind-set as qualities or characteristics. But as the gift of glossolalia and 'the tongues of angels' indicates, this hardly conforms to the modest Protestant ideals of good behaviour. When Paul speaks of spiritual gifts, he means divine powers that inhabit a porous self and take it over, activate it, and constitute it. Nor is this 
a momentary possession through ecstasy; it is clear that Paul means that this is an ongoing spirit possession through which behaviours are shaped and that one can call others to obey by resisting that other form of possession, namely possession of 'the flesh'. The 'flesh' is also for Paul a resident that is a hostile reality in a partible property (Rom 7.14 - 'of the flesh, sold into slavery under sin'), with which the apostle and his believers battle. They know both 'the fruits of (or from) the Spirit' and 'the works/fruits of (or from) the flesh' (Gal 5.16-26). Both are impartations of the divine and semi-divine that inhabit and motivate them. By the same token Paul can talk about his 'heart' coming into Philemon's household qua Onesimus. Bi-location is, on this account, a capacity that not only the gods possess, albeit in the apostle's case it is possessed in the form of gift exchange. Paul as entrepreneur is creating this order even as he reveals it, in the form of the letters he sends to communities advising, admonishing, and encouraging forms of behaviour consistent with a developing series of visions for a new set of realities. These letters are also physical objects which mediate God's presence, since they are transmissions from Christ via the apostle (Rom. 1.7; 1 Cor. 1.3; 2 Cor. 1.2; Gal. 1.3; Phil. 1.2), even as they are instantiations of the apostle's own presence.

The Letter to Philemon offers both a snapshot of de-traditionalisation in a process of the individualisation of actors as well as a window into a way of conceiving divisible and partible selves. It is unclear how these identities were practised on the ground. Paul leaves Philemon with the authority to do what he will with his slave, even as he crafts a rhetorical case that suggests otherwise. How can one be both brother and master/slave? Is it the case that de-traditionalisation only occurs in particular ritualised contexts of Eucharistic celebrations and baptism? Or is it that brotherly affection forms an incentive for masters not to treat their slaves harshly, thus investing them with an identity they might not otherwise achieve until manumission? If Philemon manumits Onesimus as an act of patronage, thus turning his slave into a client, what on-going obligations will the freedman now owe his master? Or, if Onesimus purchases his freedom, will he still share a social bond in a new form with his former master? In other words, does de-traditionalisation relate only to certain salient conditions and, if so, how does it spill over into the practices of other traditional identities and leave its mark there? Religious imagination, religious entrepreneurship, ritually conceived identity, and the practices of daily life in a new spatial imaginary (the form of the world passing away; the prison cell as agent of a new identity; a world undergoing birth pangs even as a creation comes into being) - all of these work together to reveal divisible and partible selves and to offer new possibilities of in/ dividualisation in old settings. 


\section{Appendix}

\section{Paul's letter to Philemon ${ }^{2}$}

${ }^{1}$ Paul, a prisoner of Christ Jesus, and Timothy our brother, to Philemon our dear friend and co-worker, ${ }^{2}$ to Apphia our sister, to Archippus our fellow-soldier, and to the church in your house: ${ }^{3}$ Grace to you and peace from God our Father and the Lord Jesus Christ. ${ }^{4}$ When I remember you in my prayers, I always thank my $\operatorname{God}^{5}$ because I hear of your love for all the saints and your faith towards the Lord Jesus. ${ }^{6}$ I pray that the sharing of your faith may become effective when you perceive all the good that we may do for Christ. ${ }^{7}$ I have indeed received much joy and encouragement from your love, because the hearts of the saints have been refreshed through you, my brother. ${ }^{8}$ For this reason, though I am bold enough in Christ to command you to do your duty, ${ }^{9}$ yet I would rather appeal to you on the basis of love - and I, Paul, do this as an old man, and now also as a prisoner of Christ Jesus. ${ }^{10} \mathrm{I}$ am appealing to you for my child, Onesimus, whose father I have become during my imprisonment. ${ }^{11}$ Formerly he was useless to you, but now he is indeed useful both to you and to me. ${ }^{12} \mathrm{I}$ am sending him, that is, my own heart, back to you. ${ }^{13}$ I wanted to keep him with me, so that he might be of service to me in your place during my imprisonment for the gospel $;{ }^{14}$ but I preferred to do nothing without your consent, in order that your good deed might be voluntary and not something forced ${ }^{15}$ Perhaps this is the reason he was separated from you for a while, so that you might have him back for ever, ${ }^{16}$ no longer as a slave but as more than a slave, a beloved brother - especially to me but how much more to you, both in the flesh and in the Lord. ${ }^{17}$ So if you consider me your partner, welcome him as you would welcome me. ${ }^{18}$ If he has wronged you in any way, or owes you anything, charge that to my account. ${ }^{19} \mathrm{I}$, Paul, am writing this with my own hand: I will repay it. I say nothing about your owing me even your own self. ${ }^{20}$ Yes, brother, let me have this benefit from you in the Lord! Refresh my heart in Christ. ${ }^{21}$ Confident of your obedience, I am writing to you, knowing that you will do even more than I say. ${ }^{22}$ One thing more - prepare a guest room for me, for I am hoping through your prayers to be restored to you. ${ }^{23}$ Epaphras, my fellow-prisoner in Christ Jesus, sends greetings to you, ${ }^{24}$ and so do Mark, Aristarchus, Demas, and Luke, my fellow-workers. ${ }^{25}$ The grace of the Lord Jesus Christ be with your spirit.

2 Unless otherwise stated I cite the NRSV. 


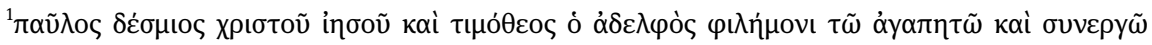

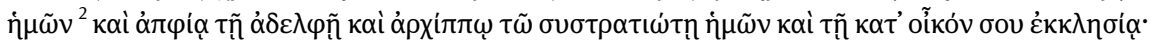

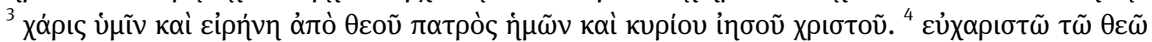

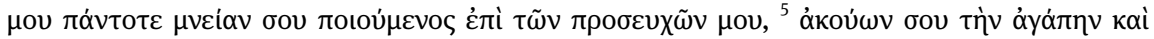

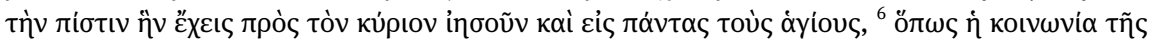

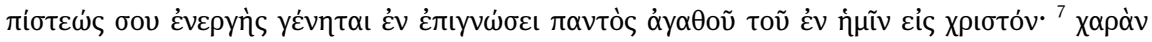

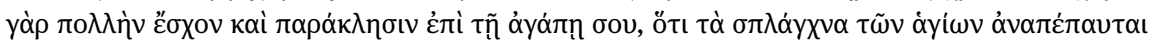

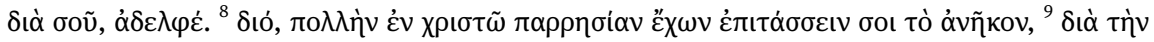

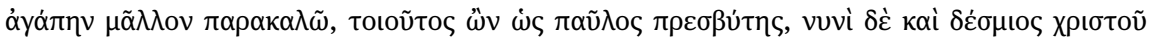

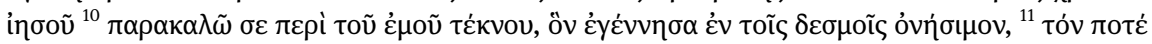

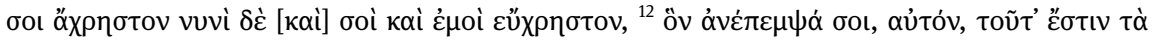

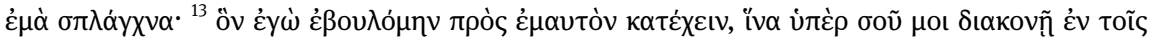

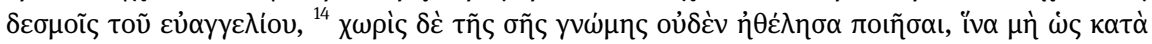

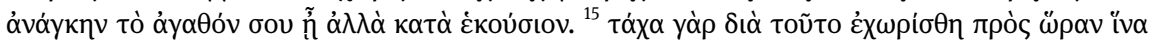

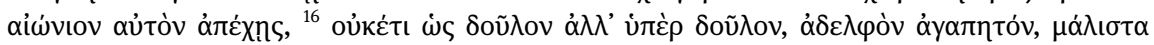

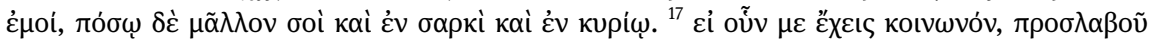

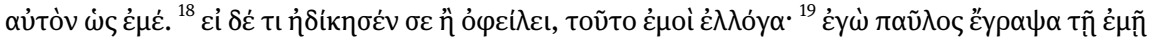

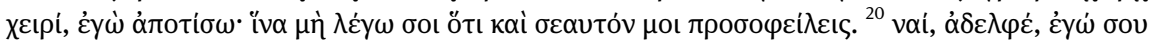

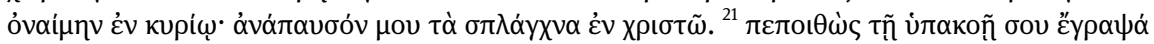

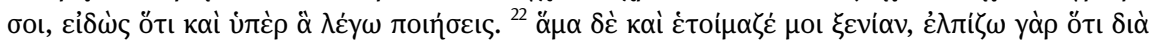

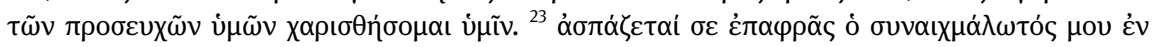

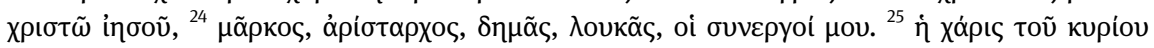

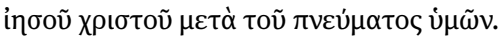

\section{References}

Arzt-Grabner, Peter. 2003. Philemon. PKNT 1. Göttingen: Vandenhoeck \& Ruprecht.

Arzt-Grabner, Peter. 2004. 'Zur Vorgeschichte des Philemonsbriefes', ZNW 95. 131-43.

Arzt-Grabner, Peter. 2008. 'How to Deal with Onesimus: Paul's Solution within the Frame of Ancient Legal and Documentary Sources.' In Philemon in Perspective: Interpreting a Pauline Letter, ed. D. F. Tolmie, Berlin: De Gruyter. 113-42.

Beker, J. C. 1982. Paul's Apocalyptic Gospel: The Coming Triumph of God. Philadelphia, PA: Fortress Press.

Bellen, H. 1071. Studien zur Sklavenflucht im römishcen Kaiserreich. FASk4. Wiesbaden.

Barclay, John M. G. 1991. 'Paul, Philemon and the Dilemma of Christian Slave-Ownership', NTS 37. 161-86.

Bartin, Mukti. 2016. 'Was Paul and Arch-Advocate of Slavery or a Liberator?' In Black Theology, Slavery and Contemporary Christianity, ed. A. G. Reddie, London: Routledge. 47-58.

Braudel, Fernand. 1949. La Méditerranée et le monde méditerranéen à l'époque de Philippe II. Paris: Colin. (ET: 2009. The Mediterranean and the Mediterranean world in the age of Philip II. 2 vols. Berkeley: University of California Press.)

Callahan, Dwight Allen. 1997. Embassy of Onesimus: The Letter to Philemon. Valley Forge: Trinity International. 
Callahan, Dwight Allen. 2012. “'Brother Saul”: An Ambivalent Witness to Freedom.' In Onesimus our Brother: Reading Religion, Race, and Culture in Philemon, Paul in Cultural Contexts, Minneapolis: Fortress Press. 143-56.

Certeau, M. 1984. The Practice of Everyday Life. Trans. S. Rendall. Berkeley: University of California Press.

Esler, Philip F. 2000. 'The Mediterranean Context of Early Christianity.' In The Early Christian World, 2 vols., ed. P. F. Esler, London/New York: Routledge. 1:3-25.

Fuchs, Martin. 2015. 'Processes of Religious Individualization: Stocktaking and Issues for the Future', Religion 45. 330-43.

Geertz, Clifford. 1973. 'Religion as a Cultural System.' In The Interpretation of Cultures, ed. C. Geertz, New York: Basic Books. 87-125.

Harrill, J. A. 1999. 'Using the Roman Jurists to Interpret Philemon: A Response to Peter Lampe', ZNW 90.135-38.

Hess, Sabine C. 2009. Person and Place: Ideas, Ideals and the Practice of Sociality in Vanua Lava, Vanuatu. New York: Berghahn Books.

Herzfeld, Michael. 1984. 'The Horns of the Mediterranean Dilemma', American Ethnologist 11. 439-54.

Herzfeld, Michael. 1987. Anthropology Through the Looking Glass: Critical Ethnography in the Margins of Europe. Cambridge: Cambridge University Press.

Lampe, Peter. 1985. 'Keine "Sklavenflucht” des Onesimus', ZNW 76. 135-7.

Lohse, E. 1973. Colossians and Philemon: A Commentary on the Epistles to the Colossians and to Philemon. Hermeneia. Philadelphia: Fortress.

Malina, Bruce. 1981. The New Testament World: Insights from Cultural Anthropology. London: SCM.

Mosko, Mark. 2010. 'Partible Penitents: Dividual Personhood and Christian Practices in Melanesia and the West', Journal of the Royal Anthropological Institute 16. 215-40.

Petersen, Norman R. 1985. Rediscovering Paul: Philemon and the Sociology of Paul's Narrative World. Philadelphia: Fortress Press.

de Pina-Cabral, J. 1989. 'The Mediterranean as a Category of Regional Comparison: A Critical View', Current Anthropology 30. 399-406.

Rüpke, Jörg. 2013. 'Individualization and Individuation as Concepts for Historical Research.' In The Individual in the Religions of the Ancient Mediterranean, ed. J. Rüpke, Oxford: Oxford University Press. 3-38.

Sanders, E. P. 1977. Paul and Palestinian Judaism: A Comparison of Patterns of Religion. Philadelphia: Fortress Press.

Stendahl, Krister. 1963. 'Paul and the Introspective Conscience of the West', Harvard Theological Review 55. 199-215.

Strathern, Marilyn. 1988. The Gender of the Gift: Problems with Women and Problems with Society in Melanesia. Berkeley: University of California Press.

Taylor, C. 1994. Sources of the Self: The Making of the Modern Identity. Cambridge: Cambridge University Press.

Taylor, C. 2007. A Secular Age. Cambridge, MASS: Belknap.

Trapp, Michael. 2007. Philosophy in the Roman Empire: Ethics, Politics and Society. London: Ashgate.

Wolter, Michael. 1993. Der Brief an die Kolosser, Der Brief an Philemon. ÖTKNT 12. Gütersloh: Gerd Mohn. 
Wolter, Michael. 2008. 'The Letter to Philemon as Ethical Counterpart of Paul's Doctrine of Justification.' In Philemon in Perspective: Interpreting a Pauline Letter, ed. D. F. Tolmie. Berlin: De Gruyter. 169-80.

Wright, N. T. 2013. Paul and the Faithfulness of God. 2 vols. Minneapolis: Fortress.

Wright, N. T. 2015. Paul and His Recent Interpreters: Some Contemporary Debates. Minneapolis: Fortress. 
